\title{
Father Damien: Centenary Commemoration
}

T. N. Jagadisan, formerly Professor at Annamalai University, and an authority on English literature, came through profound personal tragedy to devote himself to the cause of sufferers from leprosy in India, and over many years has rendered distinguished service both through the Hind Kusht Nivaran Sangh, and at a very personal level. He has made a special study of Father Damien. A commemorative speech made at the Annual Meeting of the Hind Kusht Nivaran Sangh, was published in Leprosy in India XLIV, 191-3. His address on the same subject at the All India Leprosy Workers' Conference at Sevagram in October 1973, will long be remembered by those priveleged to hear it. There is no one more appropriate to write on this theme, and we are happy to include the following abridged version of his Sevagram address which he has kindly contributed to the Leprosy Review.

\section{Father Damien: His Life and Work}

\section{T. N. JAGADISAN}

Joseph De Veuster was a man of destiny. Born at Tremelo, Belgium, in 1840, he was the youngest of 8 children. He grew up in the peace and quiet of rural life, and at an early age displayed a spirit of good neighbourliness and compassion towards others. The combination of solitude with sociability, of prayerfulness with brotherliness, marked him out for a religious life, in which he found divinity in the loneliest and most abandoned of men, and like a second Jesus bore a cross in order to redeem his fellow-men.

Joseph's father had intended that he should be a trader, but the boy had already heard the call of God and set his heart upon the religious life. The vocation of the Picpus Fathers, with its hidden life of prayer, public life of service, and sacrificial life of daily mortification appealed to Joseph's heart, and hard though it was for his father and his family, he entered the congregation of the Picpus Fathers.

In 1863, The Bishop of Hawaii asked urgently for missionaries to work in the South Sea Islands. Damien's flaming ardour so prevailed on the authorities, that although he had not yet been ordained, his wish to serve there was granted. It was a decision which was to affect not only the history of leprosy but the story of civilization.

While working as a missionary in Hawaii Island he came to know at close quarters the misery of those afflicted with leprosy. A compulsory and cruel system of segregation had come into force, imposing a lifetime of exile for leprosy patients, who were removed to the island of Molokai. The sufferings of these 
unfortunate people so touched the heart of the Bishop that he made the decision to send a resident priest to Molokai. His dilemma was, could he demand such a sacrifice of anybody, especially as according to the new regulations of the Board of Health, anyone who went to Molokai in the future would have to remain there for the rest of his life. Four priests offered to go. Among them was Damien, glowing with eagerness and sincerity, and insisting that he should be the one to be chosen. Again the hand of destiny was at work. The Bishop chose him. With one extra shirt and his breviary, which was all he had, he decided to go to Molokai that very instant. The Bishop himself sailed to Molokai and left him on the shore to embark on his sublime mission. One would fain know what were the thoughts that passed through Dámien's mind on that first fateful night under the pandanus tree. No doubt tenderness and resolution were mixed in his feelings, but waver he never did. For his unbelievable sacrifice was built on the impregnable rock of Faith.

Father Damien found Molokai in a condition of unimaginable squalor and filth. The disease had robbed its victims not only of their physical features, but of what is even more important, their morale, and that hope for the future which is so essential to continued living and progress. With a faith that leapt all bounds, with courage undaunted, with perseverance indomitable, with a physical strength matched only by his courage, he set about his task of bringing some kind of order into the island, and some kind of hope into the hearts of the abandoned, neglected, patients. With his own hands he made coffins and dug graves. He acted as carpenter and built houses, he became their engineer and brought water to the settlement from the mountains. He was doctor, nurse, compounder, priest, teacher and friend-all rolled into one. He did every thing he could to improve the lot of his parishioners. He waged many a battle with the Board of Health in Honolulu, and got supplied, medicines, clothing and food for the colony on Molokai.

One day to a hushed congregation in the church he said, "My brethren". He stopped and cleared his throat and went on, "We lepers". That was his simple announcement that he had contracted leprosy. The disease grew rapidly, and the story of his suffering spread quickly round the world bringing with it pity for the priest, admiration for his heroism, and compassion for leprosy workers. In his last years, he had a widening circle of co-workers, Brother Dutton, the "Soldier-saint" who worked in Molokai for 40 years, Dr. Mouritz, Mother Marianne, and Franciscan Sisters, none of whom contracted leprosy.

Damien's last years were full of the radiance of tenderness and friendship from his co-workers and from admiring visitors. Foremost among friends from abroad who brought Damien the sweet voice of affection and the soothing balm of consolation were 2 English non-catholics, Rev. Hugh B. Chapmen, who raised monies for Damien's work on Molokai, and Edward Clifford, the English painter who has left the world an immortal painting of Molokai and Father Damien. Indeed, even after his death visitors came to the famed Molokai of Father Damien. One such visitor, the English author R. L. Stevenson, has left an immortal literary masterpiece in his letter vindicating Father Damien against unjust slander.

Damien was no cold, aloof servant of God, regarding his service for his beloved leprosy patients as just only a means to reach the feet of the Lord. Indeed, to him God dwelt in his abandoned brethren. Hence his great warm-hearted love to his chosen parishioners, and his human tenderness and human impatience which he 
revealed in his busy life of serving them. It is remarkable in Damien-this incredible mixture of melting tenderness and grim determination, human grumbling and sublime acceptance of God's decree, of rebellion with acceptance, of impatience with resignation. We do not know which to love more, the hero in the man or the man in the hero. His letters home to his parents, brothers and sisters were human documents. They reveal the strength and tenderness of love which he had for the homeland and his kindred, and how in the midst of the devastating loneliness of spirit he looked up to the Blessed Sacrament as his sustenance and support. He wrote, "Without the Blessed Sacrament, a life like mine would be intolerable, but with the Blessed Sacrament I am always gay and work cheerfully for the relief of the poor leprosy patients" In that one sentence we see the humanity of this very human saint-his strength, his high resolve, and his terrible craving for friendship and human understanding. How Damien comes so near to us in his human-ness thereby giving us the hope that we too in our own humble way, weak as we are, can rise above our selfishness to high resolve and noble action!

Father Damien died in his 49th year, mourned not only in Molokai, but by the wider world of his admirers in many countries. The impact of his martyrdom was in the nature of a sudden, worldwide awakening to the needs of leprosy patients. Above all, he set an example that the civilised world has followed. Indeed, he lit a torch that burns for ever. Truly can it be said of him: "Not worldly deeds, not progeny, not wealth, but sacrifice and renunciation alone can confer immortality". 